\title{
Governance of electoral preferences: consensus expectations and voting intention in students of a public university
}

\author{
Cruz Garcia Lirios ${ }^{1}$ \\ Javier Carreón Guillén ${ }^{2}$ \\ Jorge Hernández Valdés ${ }^{3}$
}

Recibido: 12-08-2019

Aceptado: 16-10-2019

\section{Abstract}

The objective of this work was to validate a predictive model of voting intention. An exploratory, cross-sectional and correlation study was carried out with an intentional sample of 253 students from a public university, considering the intensive use of electronic networks. Three factors were found that explained $70 \%$ of the variance. Although the research design limits the results to the study sample, the extension of the model to other scenarios is suggested.

Keywords: governance, elections, preferences, expectations, intentions.

\footnotetext{
1. Universidad Autónoma del Estado de México, Unidad Académica Profesional Huehuetoca. Correo electrónico: cgarcial213@profesor.uaemex.mx ORCID: https://orcid.org/0000-0002-9364-6796

Google Scholar: https://scholar.google.com.mx/citations?user=7kdokoAAAj\&HI=es

2. Universidad Autónoma del Estado de México, Unidad Académica Profesional Huehuetoca Correo electrónico: javierg@uaemex.mx

ORCID: http://orcid.org/0000-0002-8915-0958

Google Scholar: https://scholar.google.com.mx/citations?user=ZS717i8AAAAJ\&hl=es

3. Universidad Autónoma del Estado de México, Unidad Académica Profesional Huehuetoca.

Correo electrónico: jorheval@uaemex.mx

ORCID: http://orcid.org/0000-0002-0001-6490-0479

Google Scholar: https://scholar.google.com/citations?user=ay_Af5AAAAAJ\&hl=es
} 


\section{Gobernanza de las preferencias electorales: expectativas de consenso e intención de voto en estudiantes de una universidad pública}

\section{Resumen}

El objetivo del presente trabajo fue establecer la contrastación de un modelo predictivo de la intención de voto. Se realizó un estudio exploratorio, transversal y correlación con una muestra intencional de 253 estudiantes de una universidad pública, considerando el uso intensivo de las redes electrónicas. Se encontraron tres factores que explicaron el $70 \%$ de la varianza. Aunque el diseño de la investigación limita los resultados a la muestra de estudio, se sugiere la extensión del modelo en otros escenarios.

Palabras clave: gobernanza, elecciones, preferencias, expectativas e intenciones.

\section{Introduction}

In the framework of presidential elections, the system of negotiation, mediation, conciliation and arbitration between actors involved in the management and administration of public resources and services is known as governance. In the case of an anticipated electoral contest, governance is a phenomenon that reflects electoral preferences, perceptions of consensus and intentions to vote for parties, candidates and democratic systems.

When looking at the effects of the anticipated electoral contest on digital networks, Facebook, Twitter, YouTube or Instagram, among others, are seen as instruments for the promotion of candidates and political platforms. These proselytize to generate ex- 
pectations and voting intentions based on electoral preferences, which are perhaps established in traditional media such as television, radio, newspapers or films, but when filtered through digital networks, propitiate a scenario of electoral debate that for the purposes of the present study allows a diagnosis of the relationship among these determining factors of the future elections.

Social psychology, through the models of reasoned action and planned behavior, has influenced the construction of an information psychology (Abu, Yunus, Majid, Jabar, Sakidin and Ahmad, 2014). In essence, both models start from the assumption that behavior is determined by the relationship between beliefs, attitudes, perceptions and intentions (García, 2007). It is a process that, in the context of the information generated on the Internet, explains consumer decisions based on rational, deliberate, planned and systematic processing.

However, psychosocial models have been modified to adjust their relationships to information processing on the Internet. These are the cases of the Technology Acceptance Model, the Trade Adoption Model and the Electronic Consumption Model (Gamal and Gebba, 2013). These models have incorporated the psychosocial variables of beliefs, attitudes, perceptions and intentions that were proposed to explain efficient, effective and effective behaviour (García, 2008).

Although Internet access is concomitant with the increase of users of social networks, these models focus on Facebook and Twitter not only for ease of use, but also for the usefulness of their protocols when it comes to disseminating personalized information (Sandoval and Saucedo, 2010). Social networks are personalized instances of information, but the information disseminated in them requires computational skills, search and information processing skills, as well as storage and dissemination capacities (Teh, Chong, Yong and Yew, 2010).

Consequently, the digital divide involves not only differences between those who access digital media and those who are margi- 
nalized or excluded, it connotes differences between Internet users seeking information for their entertainment and Internet users who process information for their knowledge and innovation (Fenoll, 2011).

Internet users are connected to an academic or professional training system that forces them to seek information and process it to show significant observable learning in the performance of their functions and in the satisfaction of their experiences (Wong, Osman and Goh, 2013).

The relevance of beliefs understood as general categories of information extends to the formation of defined attitudes such as specific categories of information, perceptions of catastrophe risk or perceptions of usefulness of information assumed as expectations that allow to anticipate scenarios of uncertainty, as well as the intentions of using the Internet to most likely process the information that is generated.

It is the relationships between the psychosocial variables that make relevant their inclusion in the psychological informational models because they explain the information processing of events distant or close to the daily life of Internet users (Yaghoubi and Bahmani, 2010). In this way, the reception of real-time information is a major factor in planning strategies or lifestyles that lessen the impact of catastrophes.

However, the tendency of informational psychological studies is to specify the psychosocial variables since beliefs are very general categorizations and cannot anticipate specific behaviors. Although attitudes are more delimited categorizations, they require perceived information to activate decisions of immediate action (García, Carreón, Hernández, Bustos, Bautista, Méndez and Morales, 2013).

Precisely because intentions are decisive probabilities of carrying out a rational, deliberate, planned and systematic action, they predict the emergence of behavior, but the information ge- 
nerated on the Internet leads to a more emotional than rational process (García, Carreón, Hernández, Bustos, Morales and Limón, 2013).

It is for this reason that the study of intentions with emotional and rational dimensions seems to be more pertinent in an unpredictable and incommensurable scenario such as electoral contests (García, Carreón, Hernández, Limón, Montero and Bustos, 2013).

\section{Method}

A non-experimental, exploratory and cross-cut quantitative study was carried out. A non-probabilistic selection of 253 students from a public university of the State of Mexico was carried out. The criterion of inclusion-exclusion was to be enrolled in the computer lab, to belong to a social network and to seek information for the preparation of tasks, works, practices, expositions, dynamics, and thesis or research reports. 120 were women $(M=19.5$ years of age and $S D=3.15$ years $)$ and 133 men $(M=22.5$ years of age and $S D$ $=4.26$ years).

Two scales of perceptions and voting intention of Carreón (2016) were used. The Consensus Perceptions Scale included 14 items related to expected benefits and consensus expectations. The Voting Intentions Scale included seven items related to the election probabilities based on an electoral preference.

The corresponding permission was requested for the application of the instrument in the classroom. Once the students were told that the study would not affect positively or negatively their partial or final scores, they were given the survey and notified that they had a maximum of 20 minutes to respond to it. Subsequently, the respondents signed their informed consent. The data were captured in the Statistical Package for Social Sciences (SPSS) and the Analysis of Moments Structures (AMOS) software in versions 10 and 6.0 respectively. 
The multivariate analyses were carried out with previous requirements of normal distribution, reliability and validity for which the parameters of kurtosis, alpha and factorial weight were used. Once the psychometric properties were established, we proceeded to estimate the correlations between each of the eight factors using the "phi" statistic. The dependency ratios were calculated with the parameter "beta" between the factor and the indicators, as well as with the "epsilon" statistic for the relations between estimation errors and the manifested variables. Finally, the validity of the structural model was performed with the chi square, goodness of fit and residual parameters.

\section{Results}

Table 1 shows alpha values above the minimum required to establish an internal consistency between the scales, which in the case of expectations (alpha of 0.893) includes two factors: expected benefits (alpha of 0.891 and $25 \%$ of the total variance explained) and consensual expectations (alpha of 0.885 with $17 \%$ of the total variance explained). In the case of the intention to vote $(0.880$ alpha and $28 \%$ of the total variance explained) a one-dimensional construct is observed.

Table 1. Descriptions of the instrument.

\begin{tabular}{|c|c|c|c|c|c|c|c|}
\hline $\mathbf{R}$ & M & $\mathbf{s}$ & K & A & F1 & F2 & F3 \\
\hline R1 & 3,14 & 1,02 & 1,34 & 0,821 & 0,401 & & \\
\hline R2 & 3,26 & 1,25 & 1,42 & 0,831 & 0,426 & & \\
\hline R3 & 3,26 & 1,36 & 1,54 & 0,852 & 0,465 & & \\
\hline R4 & 3,01 & 1,48 & 1,98 & 0,804 & 0,427 & & \\
\hline R5 & 3,27 & 1,06 & 1,02 & 0,821 & 0,406 & & \\
\hline R6 & 3,23 & 1,93 & 1,54 & 0,842 & 0,437 & & \\
\hline R7 & 3,36 & 1,02 & 1,23 & 0,861 & 0,487 & & \\
\hline
\end{tabular}




\begin{tabular}{|c|c|c|c|c|c|c|c|}
\hline $\mathbf{R}$ & $\mathbf{M}$ & $\mathbf{S}$ & K & A & F1 & F2 & F3 \\
\hline R8 & 3,27 & 1,24 & 1,43 & 0,831 & & 0,501 & \\
\hline R9 & 3,01 & 1,60 & 1,54 & 0,805 & & 0,503 & \\
\hline R10 & 3,27 & 1,04 & 1,89 & 0,861 & & 0,503 & \\
\hline R11 & 3,28 & 1,82 & 1,71 & 0,872 & & 0,591 & \\
\hline R12 & 3,54 & 1,57 & 1,36 & 0,831 & & 0,523 & \\
\hline R13 & 3,82 & 1,06 & 1,43 & 0,853 & & 0,504 & \\
\hline R14 & 3,05 & 1,36 & 1,54 & 0,832 & & 0,503 & \\
\hline R15 & 3,05 & 1,26 & 1,89 & 0,805 & & & 0,618 \\
\hline R16 & 3,58 & 1,42 & 1,23 & 0,806 & & & 0,681 \\
\hline R17 & 3,95 & 1,50 & 1,43 & 0,825 & & & 0,671 \\
\hline R18 & 3,21 & 1,06 & 1,54 & 0,816 & & & 0,682 \\
\hline R19 & 3,27 & 1,04 & 1,67 & 0,841 & & & 0,693 \\
\hline R20 & 3,74 & 1,03 & 1,90 & 0,827 & & & 0,618 \\
\hline R21 & 3,49 & 1,21 & 1,78 & 0,837 & & & 0,603 \\
\hline
\end{tabular}

Source: prepared with study data.

Extraction method: main axes, rotation promax. Adequacy and Sphericity $\left[x^{2}=324.25(45 \mathrm{gl}) \mathrm{p}=0.000 ; \mathrm{KMO}=0.672\right] \mathrm{M}=$ Mean, $\mathrm{S}=$ Standard Deviation, $\mathrm{A}=$ Crombach's alpha with values suppressing that of the item. $\mathrm{F} 1=$ Expected Benefits of the Electoral Contest ( $25 \%$ of the total variance explained), F2 = Consensus Expectations ( $17 \%$ of the total variance explained). $\mathrm{F} 3=$ Intention to vote ( $28 \%$ of the total variance explained). Each item has response options such as: $0=$ unlikely, $1=$ very unlikely, $2=$ unlikely, $3=$ probable, 4 = very likely.

However, the low correlations between item and factor expressed in factorial weights indicate a simple factorial structure of oblique type. That is to say, the correlation between the factors or 
dimensions - expected benefits and consensus expectations of the Consensus Expectations Scale- seems to indicate an association between the expected benefits of the electoral contests with respect to the consensus expectations. In this sense, electoral preferences would be the starting point to activate the voting intention process, since it is consensus expectations such as distrust, discontent, denunciation, responsibility and social division that determine the intention to vote $(0,56)$.

Finally, the adjustment and residual indicators $[x 2=214.35$ (47 gl) $\mathrm{p}=0.007 ; \mathrm{GFI}=0.990 ; \mathrm{CFI}=0.997 ; \mathrm{RMSSEA}=0.001]$ suggest the acceptance of the null hypothesis regarding the co-correspondence between the theoretical relations of the variables with respect to the findings.

\section{Final considerations}

From an exploratory factorial structure of main axes and with simple and oblique promax rotation in which the correlations among the factors of the Consensus Expectation Scale stand out, the present work has provided a provisional model to the study of the electoral preferences and their effects on the intention to vote.

Non-experimental design and non-probabilistic selection, however, limit the results to students of the public university of the State of Mexico. We hope to carry out the test of the model in a representative sample of students from the Mexican city in order to anticipate the results of the state elections to be held in 2017 and the federal elections of 2018.

Digital networks as a framework of agendas, advertisements, opinions, preferences and intentions represent a small percentage of the electorate that will participate in the aforementioned elections. This is because unlike traditional media, digital networks not only reproduce information but also produce expectations in potential voters. 
Such differences between the Internet, television, radio, the press or cinema make it necessary to reflect on the studies of mass communication centered on the establishment of agenda, the framing effect and its consequences on the intentions to vote. That is to say that the study of the digital networks supposes a differentiation of sectors even among the users of Facebook, Twitter, YouTube and Instagram with respect to others of digital networks.

Therefore, it is necessary to study in greater depth the similarities and differences of users of digital networks with respect to potential voters in the elections in question.

\section{References}

Abu, F., Yunus, A., Majid, I., Jabar, J., Sakidin, H. \& Ahmad, A. (2014). Technology Acceptance Model (TAM): Empowering smart customer to participate in electricity supply system. Journal of Technology Management and Technopreneurship, 2(1), 85-94.

Ballesteros, R., Gil, M., Gómez, S. \& Gil, B. (2010). Propiedades psicométricas de un instrumento de evaluación de la adicción al cibersexo. Psicothema, 22, 1048-1063.

Barrantes, H. A., Beltrán, J. E. P., \& Pérez, F. A. R. (2016). Perfil del estudiante de pregrado de la Facultad de Estudios a Distancia de la Universidad Militar Nueva Granada. Revista Interamericana de Investigación, Educación y Pedagogía, RIIEP, 9(2). DOI: https://doi. org/10.22490/25391887.1948

Carreón, J. (2016). Desarrollo humano: Gobernanza, Desarrollo Local y Emprendimiento Social. México: UNAM.

Chuo, Y., Tsai, C., Lan, Y. \& Tsai, C. (2011). The effect of organizational support, self efficacy and computer anxiety on the usage intention of 
e-learning system in hospital. African Journal of Business Management, 5, 5518-5523.

Fenoll, V. (2011). Usuarios activos y pasivos. La interactividad de la audiencia en los medios digitales. Revista de Ciencias Sociales, 51, 1-26.

Fuente, A., Herrero, J. \& Gracia, E. (2010). Internet y apoyo social: sociabilidad online y ajuste psicosocial en la sociedad de la información. Acción Psicológica, 7, 9-15.

Gamal, M. \& Gebba, T. (2013). Mobile banking adoption: an examination of Technology Acceptance Model and Theory of Planned Behavior. International Journal of Business Research and Development, 2(1), 3550.

García, C. (2007). La percepción de utilidad del comercio electrónico. Enseñanza e Investigación en Psicología, 12(2), 409-420.

García, C. (2008). La brecha digital de las generaciones futuras. Entelequia, 8, 61-72.

García, C. (2011). Estructura del consumo electrónico. Psicología Política, 9(26), 74-82.

García, C. (2012). Estructura híbrida de los determinantes del consumo electrónico. Revista de Psicología Gepu, 3(2), 43-53.

García, C. (2013). Actitud hacia la utilidad y el riesgo en las redes sociales. Folios, 29, 91-103.

García, C., Carreón, J., Hernández, J., Bustos, J., Bautista, M., Méndez, A. \& Morales, M. (2013). Confiabilidad y validez de un instrumento de medición de búsqueda en Internet. Revista de Psicología de la Universidad de Antioquia, 5(1), 27-34.

García, C., Carreón, J., Hernández, J., Bustos, J., Morales, M. \& Limón, G. (2013). dimensiones utilitarista y eficientista del uso del uso de Internet. Visión Gerencial, 12(2), 281-292. 
García, C., Carreón, J., Hernández, J., Limón, G., Montero, M. \& Bustos, J. (2013). determinantes perceptuales de la intención de uso de Internet para el desarrollo del capital humano. Forum Empresarial, 18(1), 95-117.

García, C., Carreón, J., Hernández, J., Montero, M. \& Bustos, J. (2012). Confiabilidad y validez de un instrumento que mide la percepción de eficiencia en el uso de Internet en una biblioteca pública de México, Distrito Federal. Invurnus, 7(2), 3-11.

Groshek, J. (2011). Media, instability, a democracy: examining the granger causal relationships of the 122 countries from 1943-2003. Journal of Communication, 61, 1161-1182.

Hee, D. \& Mc Daniel, S. (2011). Using an extended Technology Acceptance Model in exploring antecedents to adopting fantasy sports league websites. International Journal of Sport Marketing \& Sponsorships, 17, 240-253.

López, L. \& López, J. (2011). Los modelos de adopción de tecnologías de información desde el paradigma actitudinal. Cuadernos Ebape, 9, 176196.

Mao, Y., Richter, M., Burns, K. \& Chaw, J. (2012). Homelessness coverage, social reality, and media ownerships: comparing a national newspapers with to regional newspapers in Canada. Mass Communication \& Journalism, 2, 1-7.

Nisbet, E., Stoycheff, E. \& Pearce, K. (2012). Internet use and democratic demand: a multinational, multinivel model of Internet use and citizen attitudes about democracy. Journal of Communication, 62, 249-265.

Núñez, D., Ochoa, E., Vales, J., Fernández, M. \& Paz, G. (2013). Actitudes y hábitos asociados al uso de las TIC's en alumnos de psicología. Psicología para América Latina, 25, 91-114.

Orantes, S. (2011). Viabilidad del Modelo de la Aceptación de la Tecnología en las empresas mexicanas. Una aproximación a las actitudes 
y percepciones de los usuarios de las tecnologías de la información. Revista Digital Universitaria, 12, 1-15.

Ortiz, J. G., \& Buitrago, H. (2017). La evaluación en la tradición educativa colombiana. Instrumento de clasificación social. Revista Interamericana de Investigación, Educación y Pedagogía, RIIEP, 10(1), 145-171. DOI: https://doi.org/10.15332/s1657-107X.2148

Phan, K. \& Daim, T. (2011). Exploring technology acceptance for mobile services. Journal of Industrial Engineering and Management, 4(2), 339360.

Sandoval, R. \& Saucedo, N. (2010). Grupos de interés en las redes sociales: el caso de Hi5 y Facebook en México. Educación y Humanidades, 4, 132-142.

Shrrof, R., Denenn, C. \& Ng, E. (2011). Analysis of the Technology Acceptance Model in examining student's behavioral intention to use an e-portfolio system. Australasian Journal of Educational Technology, $27,600-618$.

Simsek, A. (2011). The relationships between computer anxiety and computer self efficacy. Contemporary Educational Technology, 2, 177187

Teh, P., Chong, C., Yong, C. \& Yew, S. (2010). Internet self-efficacy, computer self-efficacy, and cultural factor on knowledge sharing behavior. African Journal of Business Management, 4, 4086-4095.

Wong, K., Osman, R. \& Goh, P. (2013). Understanding student teacher's behavioral intention to use technology: Technology Acceptance Model (TAM) validation and testing. International Journal of Instruction, 6(1), 90-104.

Yaghoubi, N. \& Bahmani, E. (2010). Factors affecting adoption of online banking. An integration Technology Acceptance Model and Theory of Planned Behavior. International Journal of Business and Management, 5(9), 159-165. 